\title{
Hydrogen Bonded Oligohydrazide Foldamers and Their Recognition for
}

\section{Saccharides}

Jun-Li Hou, ${ }^{\dagger}$ Xue-Bin Shao, ${ }^{\dagger}$ Guang-Ju Chen, ${ }^{\ddagger}$ Yan-Xia Zhou, ${ }^{\ddagger}$ Xi-Kui Jiang, ${ }^{\dagger}$ Zhan-Ting $\mathrm{Li}^{\dagger}{ }^{\dagger}$ *

${ }^{\dagger}$ Shanghai Institute of Organic Chemistry, Chinese Academy of Sciences, 354 Fenglin Lu, Shanghai 200032, China

${ }^{\ddagger}$ Department of Chemistry, Beijing Normal University, Beijing 100875, China

Supporting Information 


\section{Contents}

Figure 1. Partial ${ }^{1} \mathrm{H}$ NMR NOESY spectrum of $\mathbf{1}$ S3

Figure 2. Partial ${ }^{1} \mathrm{H}$ NMR NOESY spectrum of 2 . S4

Figure 3. Partial ${ }^{1} \mathrm{H}$ NMR NOESY spectrum of $3 . \quad$ S5

Figure 4. Partial ${ }^{1} \mathrm{H}$ NMR NOESY spectrum of $4 . \quad$ S6

Figure 5. ${ }^{1} \mathrm{H}$ NMR NOESY spectrum of $\mathbf{5} . \quad$ S7

Figure 6. Partial ${ }^{1} \mathrm{H}$ NMR NOESY spectrumof $5 . \quad$ S8

Figure 7. Partial ${ }^{1} \mathrm{H}$ NMR COSY spectrum of $6 . \quad$ S9

Figure 8. ${ }^{1} \mathrm{H}$ NMR NOESY spectrum of $6 . \quad$ S10

Figure 9. Partial ${ }^{1} \mathrm{H}$ NMR NOESY spectrum of $6 . \quad$ S11

Figure 10. Partial ${ }^{1} \mathrm{H}$ NMR NOESY spectrum of $6 . \quad \mathrm{S} 12$

Figure 11. ${ }^{1} \mathrm{H}$ NMR COSY spectrum of $34 . \quad$ S13

Figure 12. Partial ${ }^{1} \mathrm{H}$ NMR COSY spectrum of $34 . \quad$ S14

Figure 13. Partial ${ }^{1} \mathrm{H}$ NMR COSY spectrum of the mixture of 6 and $34 . \quad$ S15

Figure 14. Partial ${ }^{1} \mathrm{H}$ NMR COSY spectrum of the mixture of 6 and $34 . \quad$ S16

Figure 15. Partial ${ }^{1} \mathrm{H}$ NMR NOESY spectrum of the mixture of 6 and $34 . \quad$ S17

Figure 16. Partial ${ }^{1} \mathrm{H}$ NMR NOESY spectrum of the mixture of 6 and $34 . \quad$ S18

Figure 17. Partial ${ }^{1} \mathrm{H}$ NMR NOESY spectrum of the mixture of 6 and $34 . \quad$ S19

Figure 18. Concentration-dependent CD spectra of complexes between 6 and 34 S20

Figure 19. Concentration-dependent UV spectra of $7 . \quad$ S20

Figure 20. ${ }^{1} \mathrm{H}$ NMR spectrum $(400 \mathrm{MHz})$ of $7(0.1 \mathrm{mM})$ in $\mathrm{CDCl}_{3}$ at $23{ }^{\circ} \mathrm{C} . \quad \mathrm{S} 21$

Figure 21. ${ }^{1} \mathrm{H}$ NMR spectrum (400 MHz) of $7(2 \mathrm{mM})$ in DMSO- $\mathrm{d}_{6}$ at $23{ }^{\circ} \mathrm{C}$. $\quad$ S21

Figure 22. ${ }^{1} \mathrm{H}$ NMR spectrum $(400 \mathrm{MHz})$ of $6(2 \mathrm{mM})$ in $\mathrm{DMSO}^{-\mathrm{d}_{6}} / \mathrm{CDCl}_{3}(9: 1 \mathrm{v} / \mathrm{v})$ at $23{ }^{\circ} \mathrm{C}$.

Figure 23. Partial ${ }^{1} \mathrm{H}$ NMR NOESY spectrum $(400 \mathrm{MHz})$ of $6(8.0 \mathrm{mM})$ in $\mathrm{CDCl}_{3}$ (mixing time $=0.5 \mathrm{~s}$ ).

Figure 24. Partial ${ }^{1} \mathrm{H}$ NMR NOESY spectrum $(400 \mathrm{MHz})$ of $6(8.0 \mathrm{mM})$ in $\mathrm{CDCl}_{3}$ (mixing time $=0.25 \mathrm{~s})$. S24 


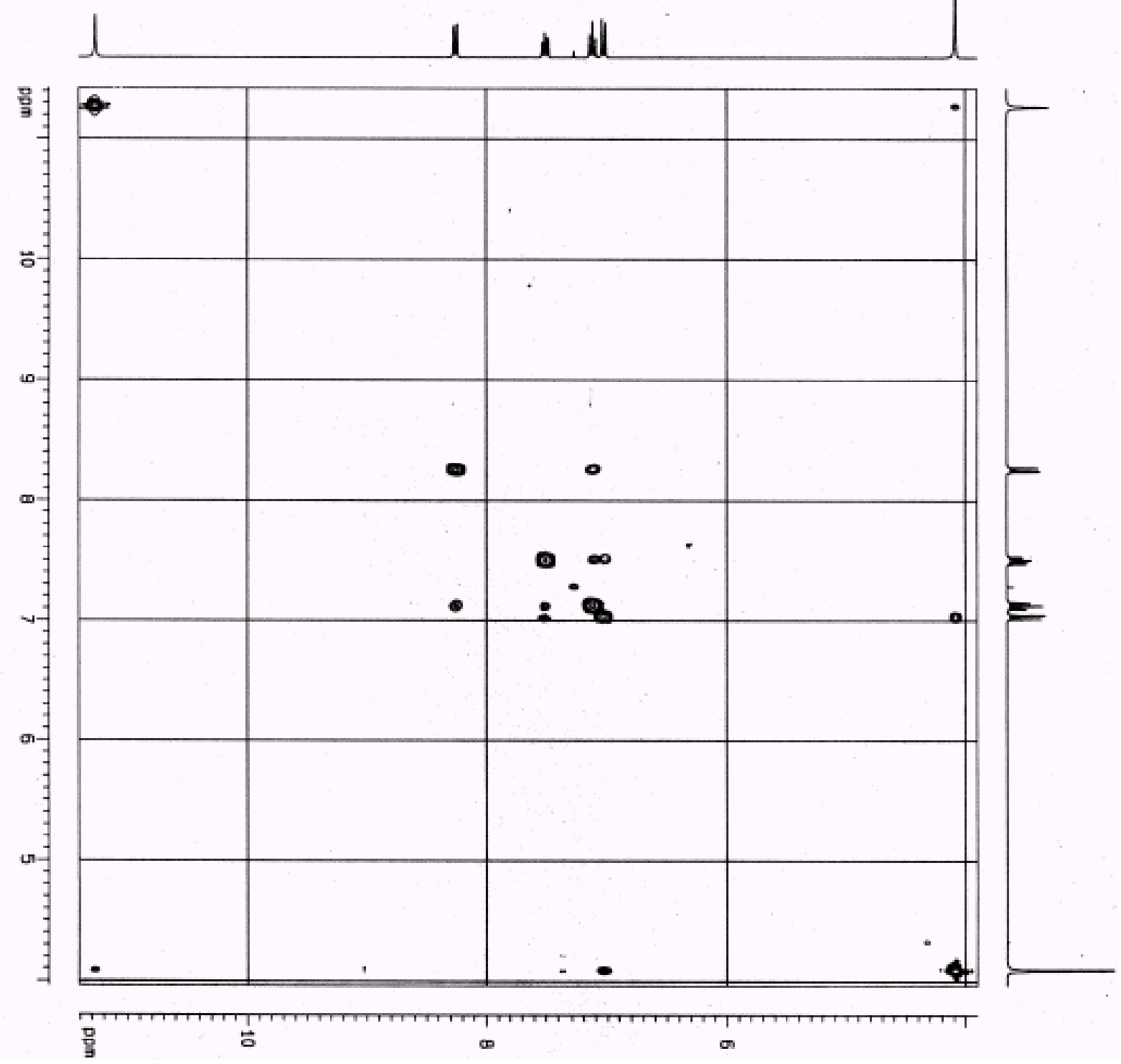

Figure 1. Partial ${ }^{1} \mathrm{H}$ NMR NOESY spectrum (400 MHz) of $1(5.0 \mathrm{mM})$ in $\mathrm{CDCl}_{3}$ at $23{ }^{\circ} \mathrm{C}$ (mixing time $=1 \mathrm{~s}$ ). 


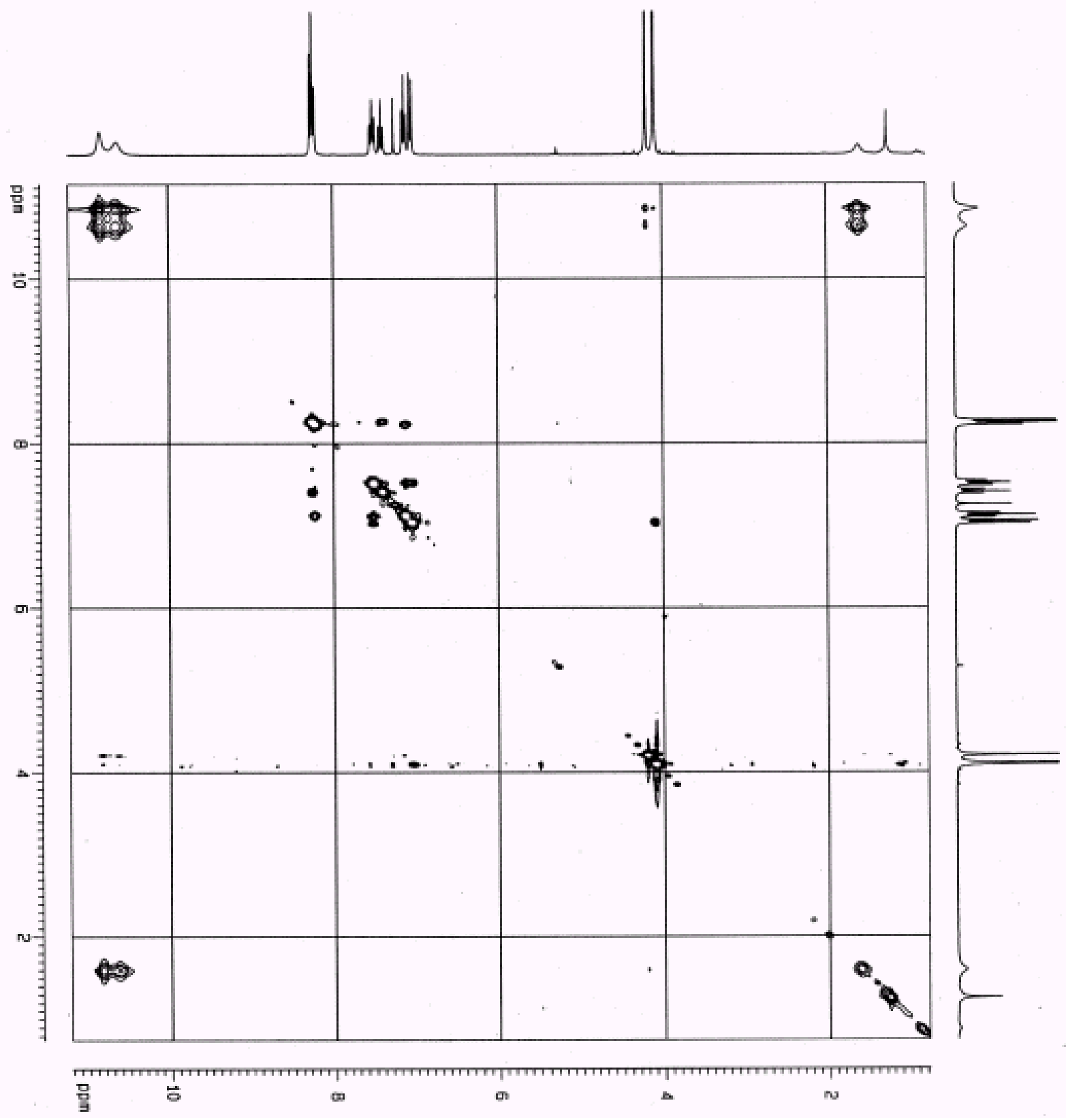

Figure 2. Partial ${ }^{1} \mathrm{H}$ NMR NOESY spectrum $(400 \mathrm{MHz})$ of $2(5.0 \mathrm{mM})$ in $\mathrm{CDCl}_{3}$ at $23{ }^{\circ} \mathrm{C}$ (mixing time $=1 \mathrm{~s}$ ). 


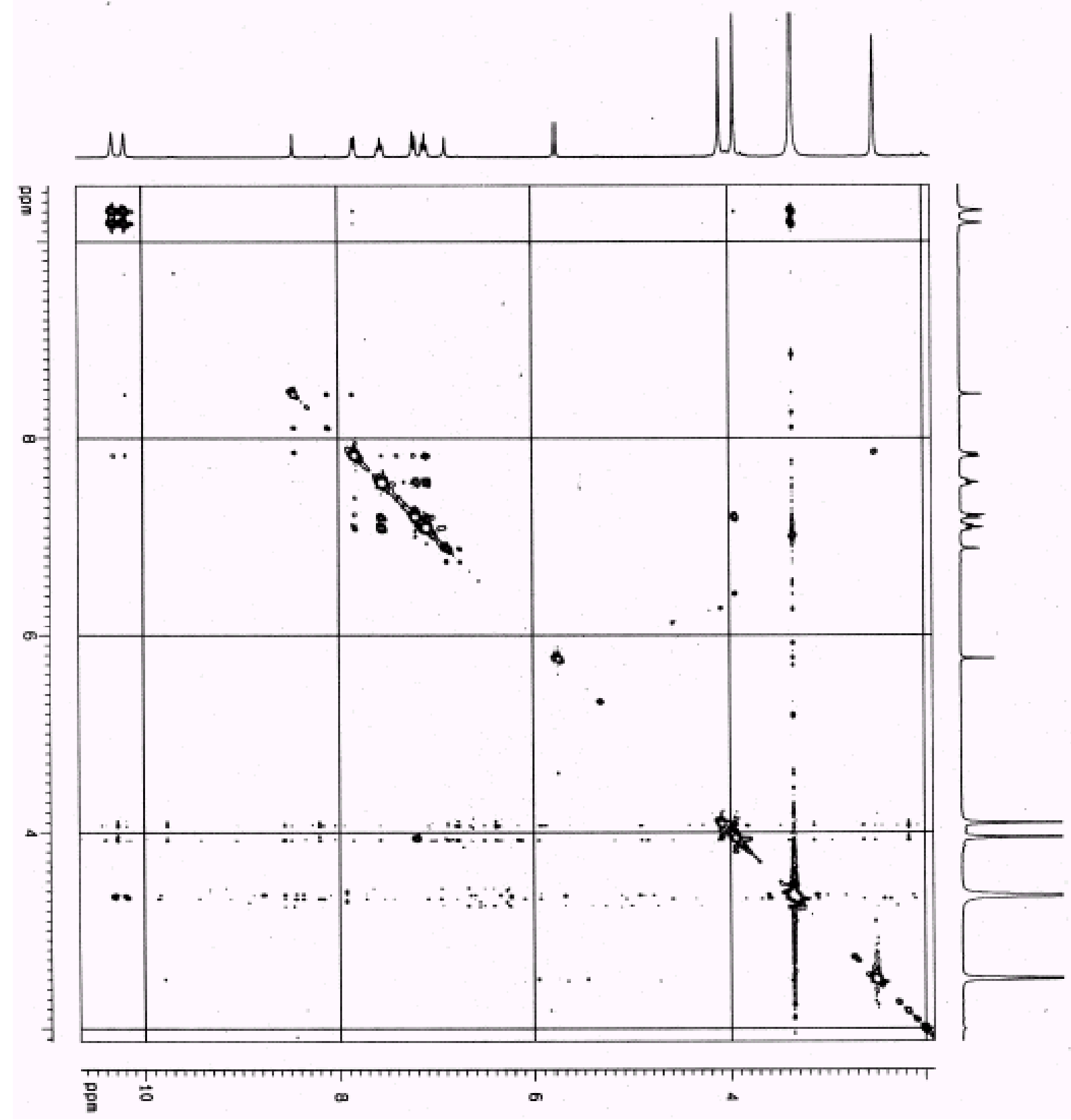

Figure 3. Partial ${ }^{1} \mathrm{H}$ NMR NOESY spectrum (400 MHz) of $3(5.0 \mathrm{mM})$ in DMSO- $\mathrm{d}_{6}$ at $23{ }^{\circ} \mathrm{C}$ (mixing time $=1 \mathrm{~s}$ ). The solubility of this compound is low in chloroform. 


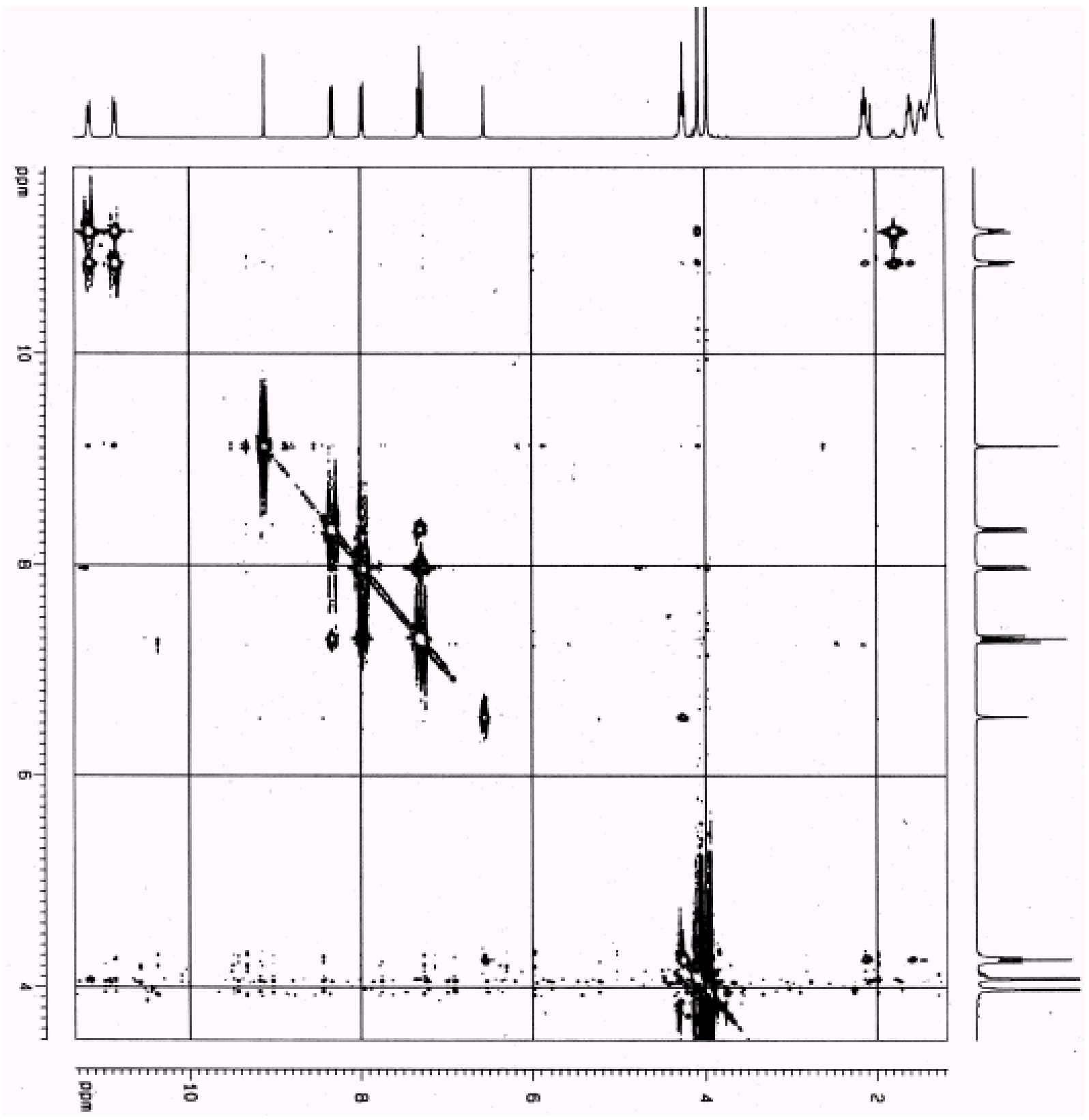

Figure 4. Partial ${ }^{1} \mathrm{H}$ NMR NOESY spectrum (400 MHz) of $4(5.0 \mathrm{mM})$ in $\mathrm{CDCl}_{3}$ at $23{ }^{\circ} \mathrm{C}$ (mixing time $=1 \mathrm{~s}$ ). 


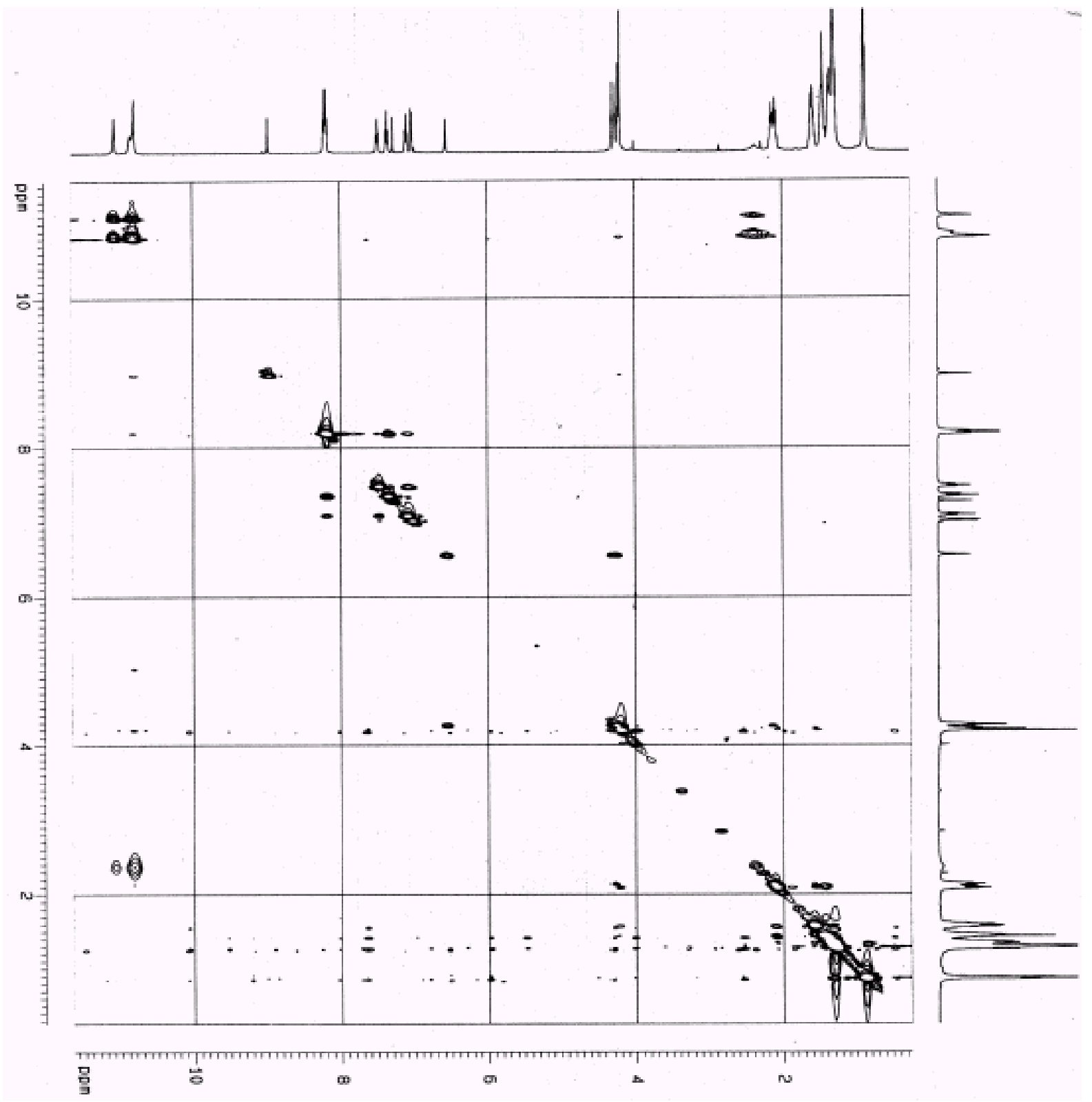

Figure 5. ${ }^{1} \mathrm{H}$ NMR NOESY spectrum $(400 \mathrm{MHz})$ of $5(5.0 \mathrm{mM})$ in $\mathrm{CDCl}_{3}$ at $23{ }^{\circ} \mathrm{C}$ (mixing time $=1 \mathrm{~s}$ ). 


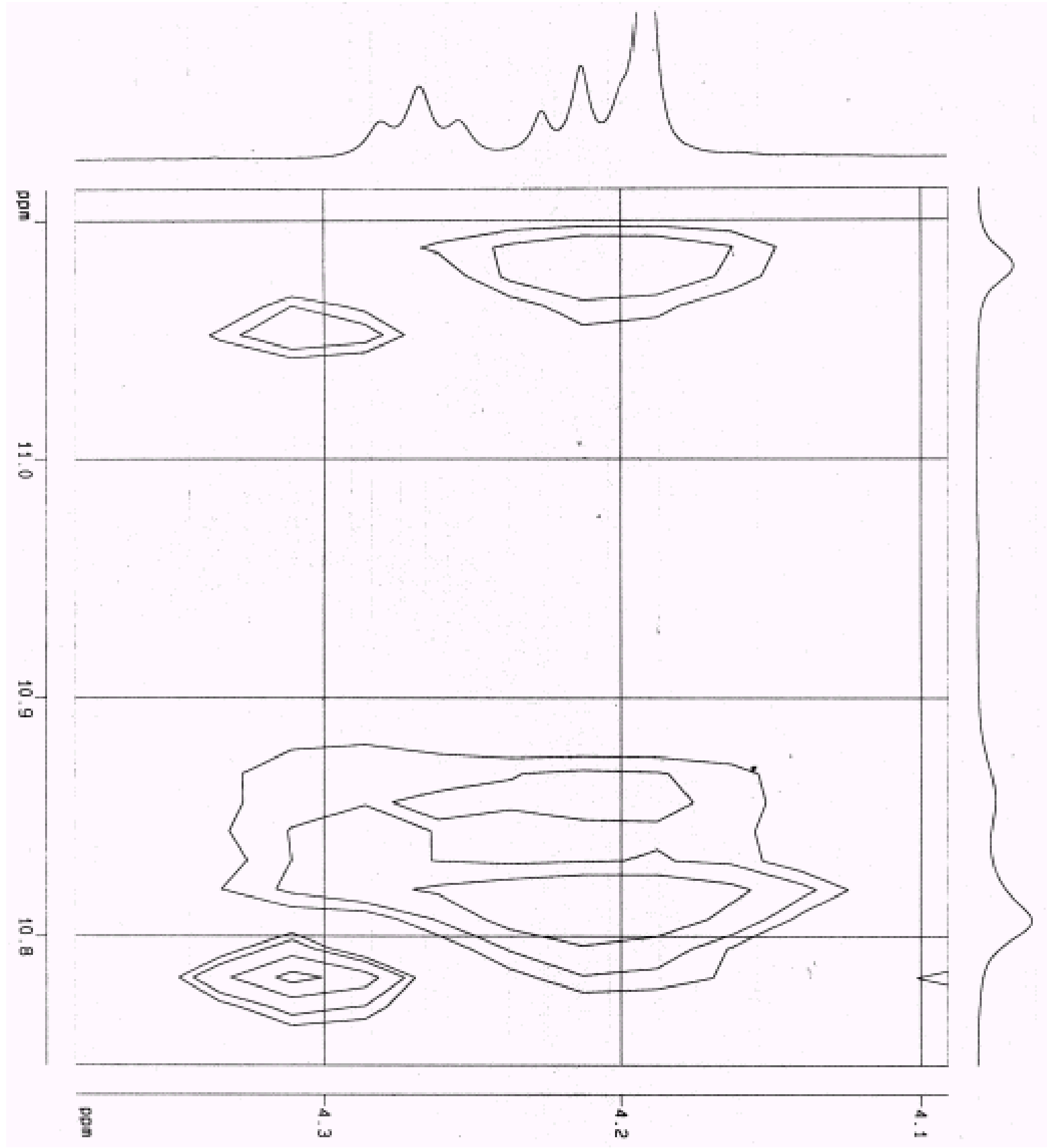

Figure 6. Partial ${ }^{1} \mathrm{H}$ NMR NOESY spectrum $(400 \mathrm{MHz})$ of $5(5.0 \mathrm{mM})$ in $\mathrm{CDCl}_{3}$ at $23{ }^{\circ} \mathrm{C}$ (mixing time $=1 \mathrm{~s}$ ).

SB 

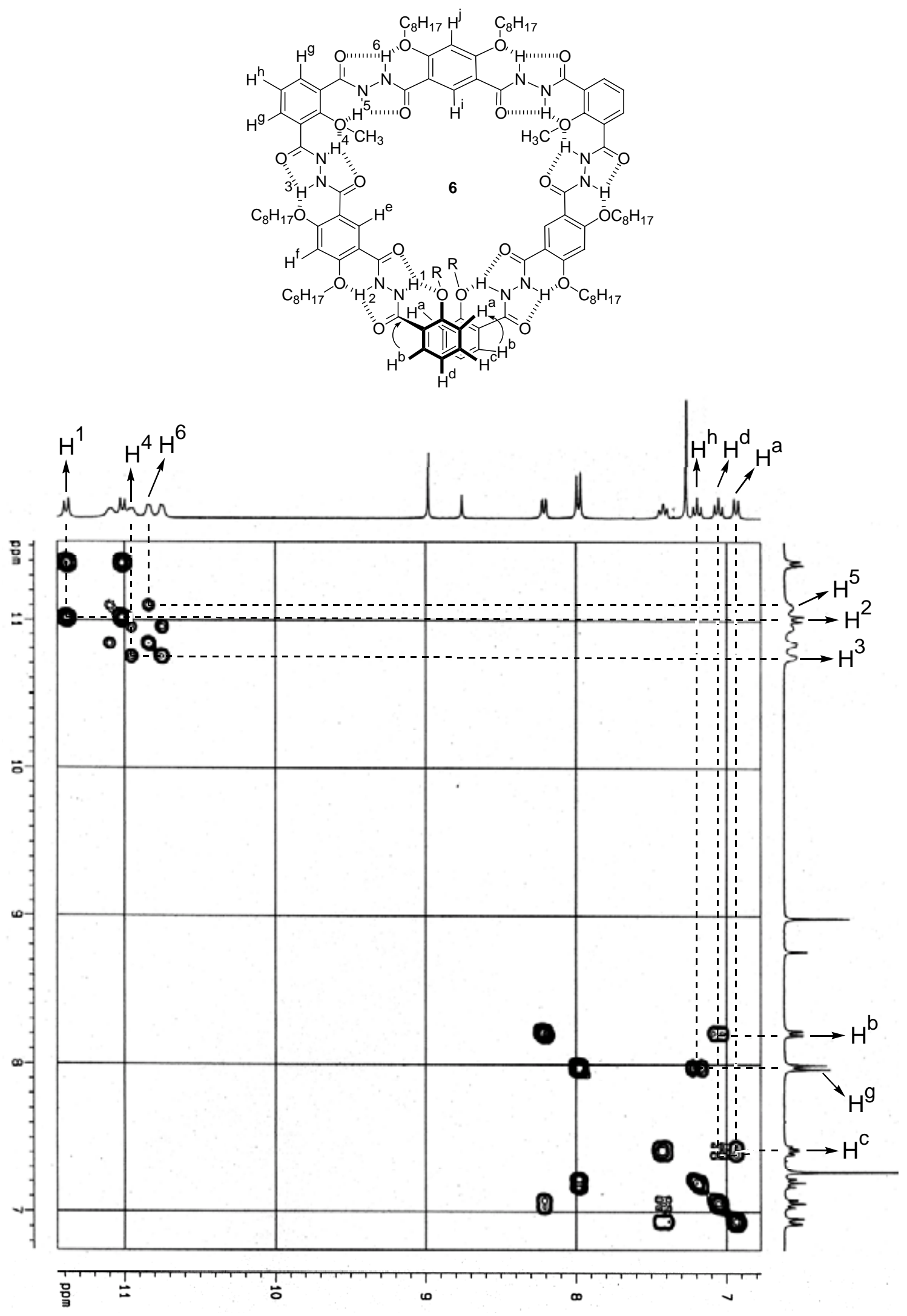

Figure 7. Partial ${ }^{1} \mathrm{H}$ NMR COSY spectrum $(400 \mathrm{MHz})$ of $6(8.0 \mathrm{mM})$ in $\mathrm{CDCl}_{3}$ at $23{ }^{\circ} \mathrm{C}$. 


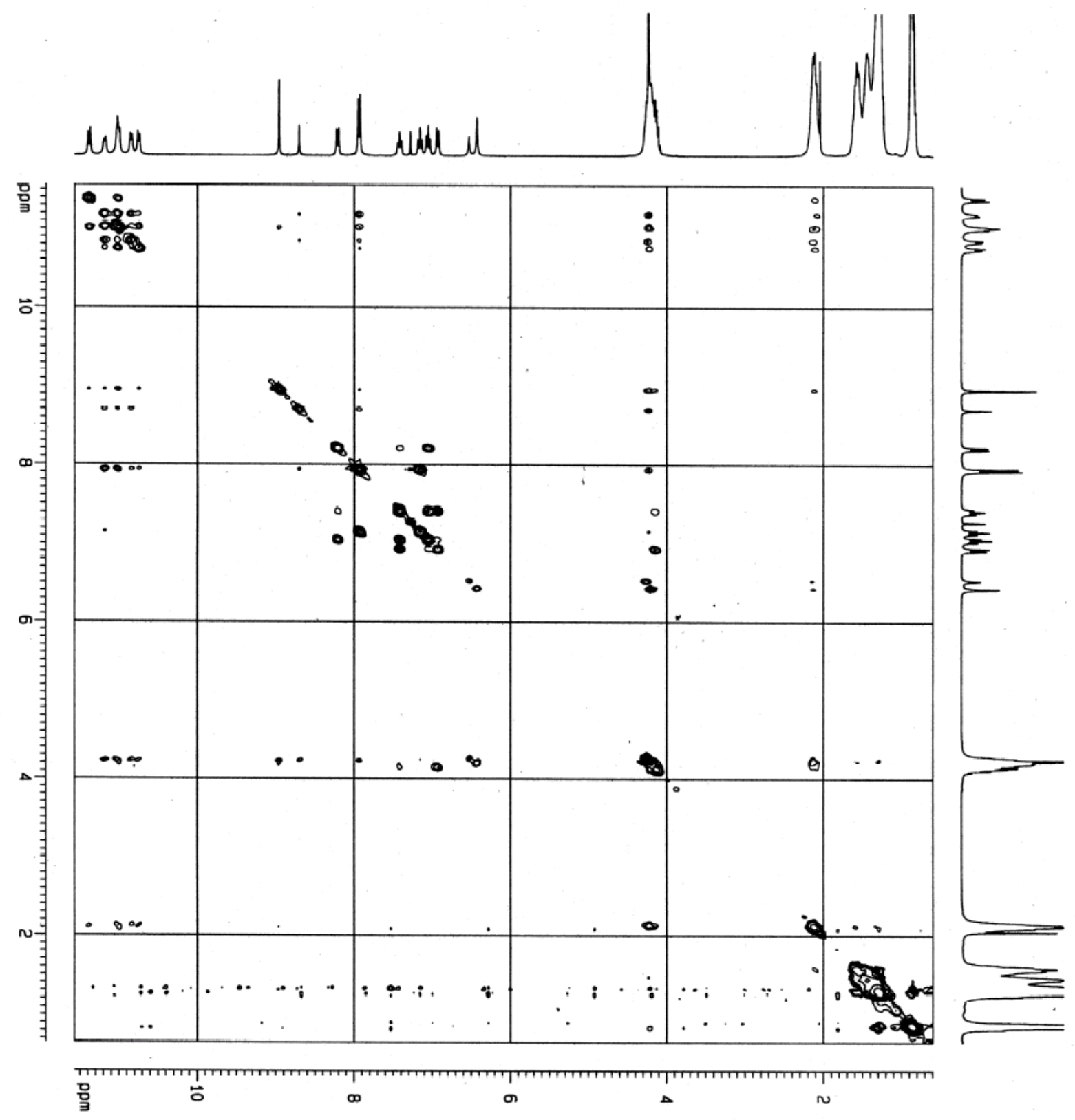

Figure 8. ${ }^{1} \mathrm{H}$ NMR NOESY spectrum $(400 \mathrm{MHz})$ of $6(8.0 \mathrm{mM})$ in $\mathrm{CDCl}_{3}($ mixing time = $1 \mathrm{~s})$. 


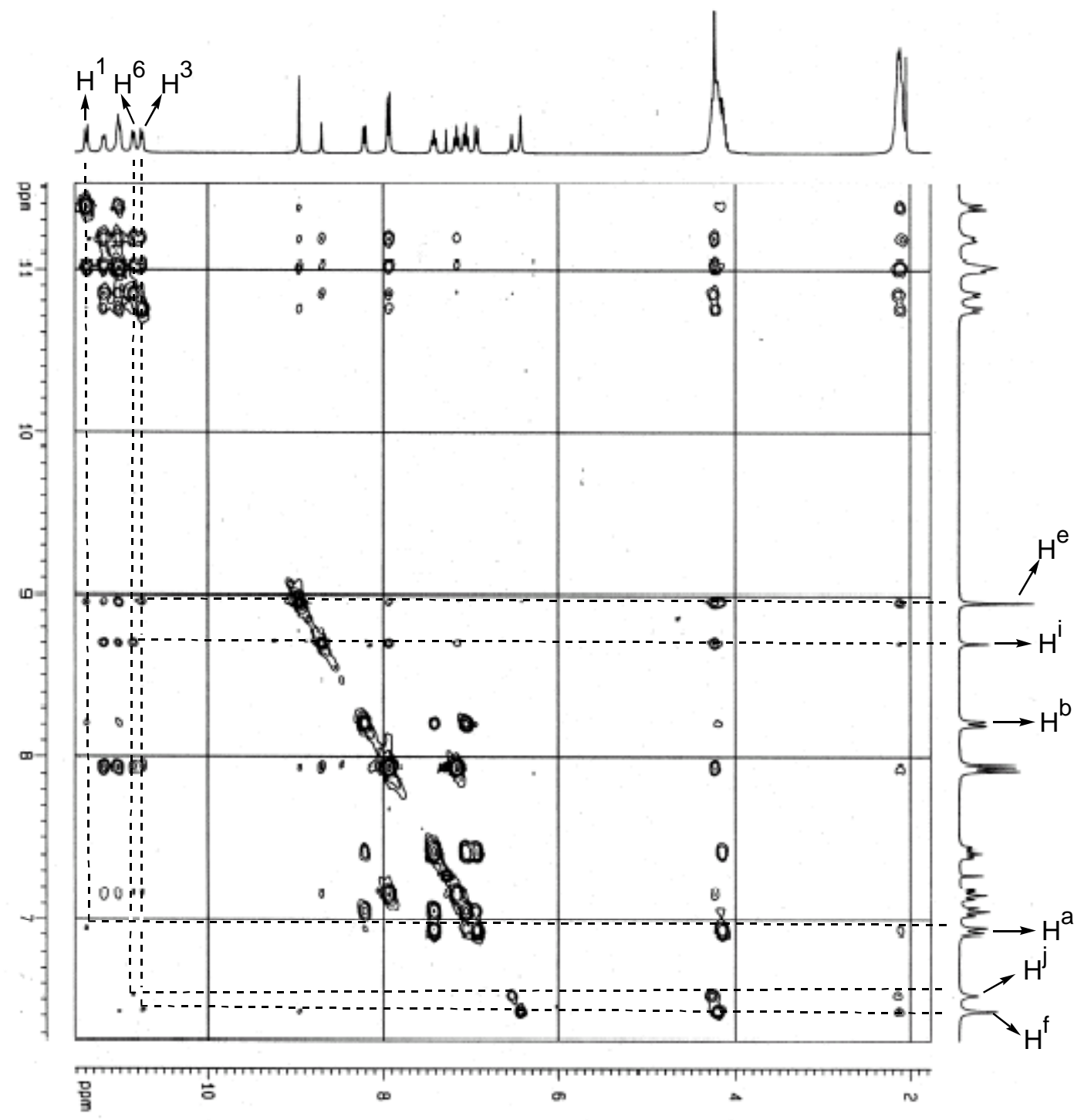

Figure 9. Partial ${ }^{1} \mathrm{H}$ NMR NOESY spectrum $(400 \mathrm{MHz})$ of $6(8.0 \mathrm{mM})$ in $\mathrm{CDCl}_{3}$ (mixing time=1s). 


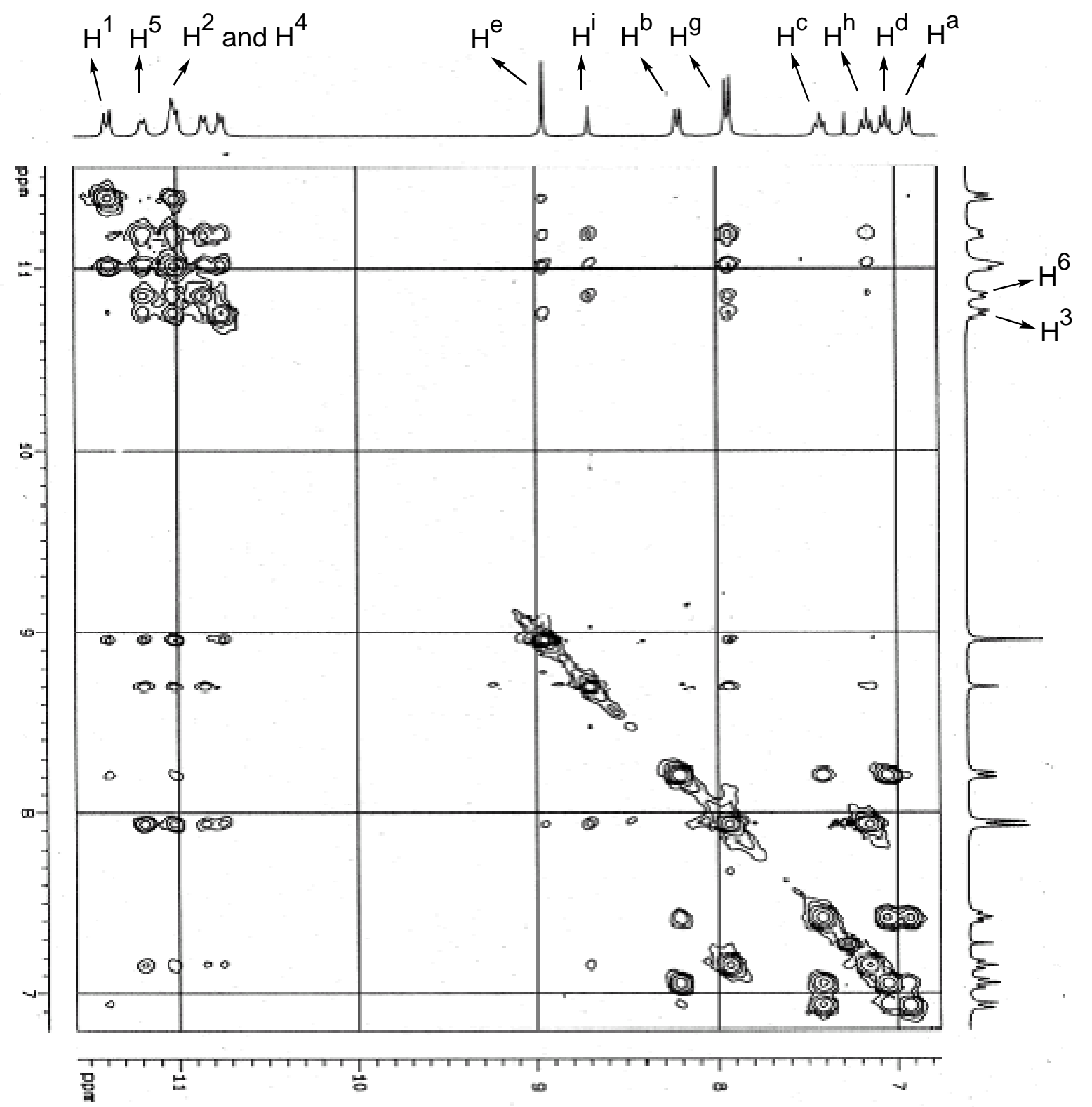

Figure 10. Partial ${ }^{1} \mathrm{H}$ NMR NOESY spectrum $(400 \mathrm{MHz})$ of $6(8.0 \mathrm{mM})$ in $\mathrm{CDCl}_{3}$ (mixing time $=1 \mathrm{~s})$. 

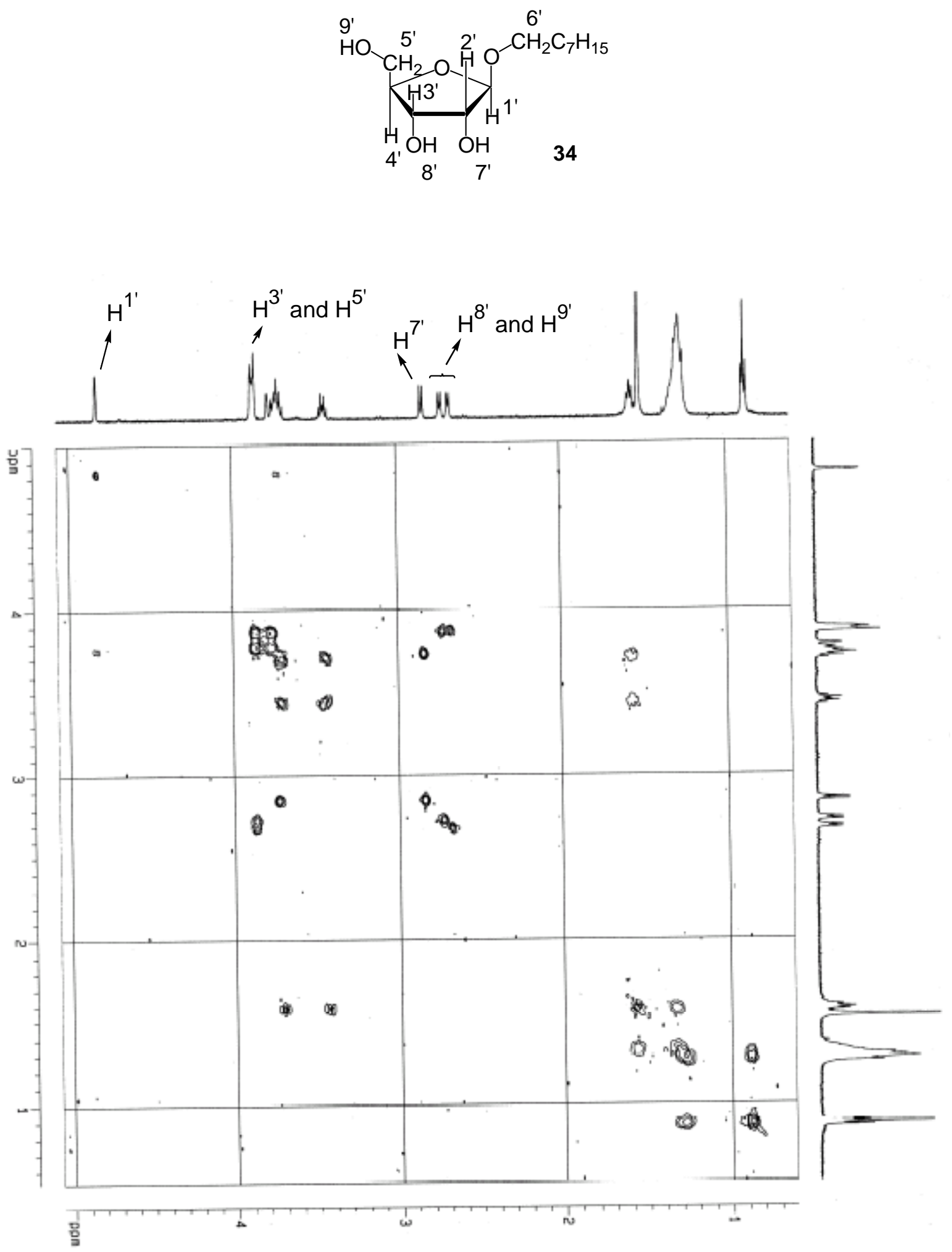

Figure 11. ${ }^{1} \mathrm{H}$ NMR COSY spectrum $(500 \mathrm{MHz})$ of $34(8.0 \mathrm{mM})$ in $\mathrm{CDCl}_{3}$ at $23{ }^{\circ} \mathrm{C}$. 

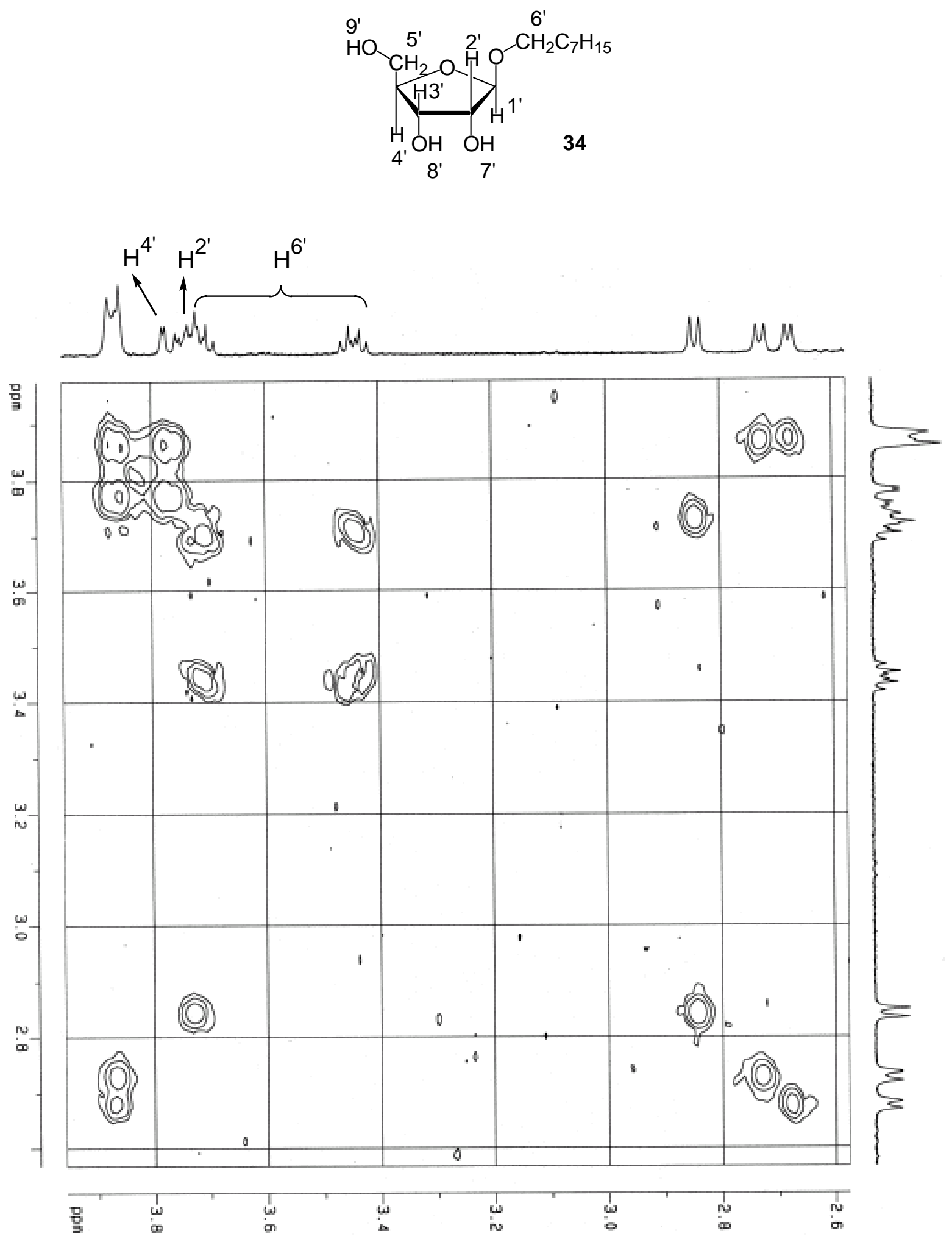

Figure 12. Partial ${ }^{1} \mathrm{H}$ NMR COSY spectrum $(500 \mathrm{MHz})$ of $34(8.0 \mathrm{mM})$ in $\mathrm{CDCl}_{3}$ at $23^{\circ} \mathrm{C}$. 

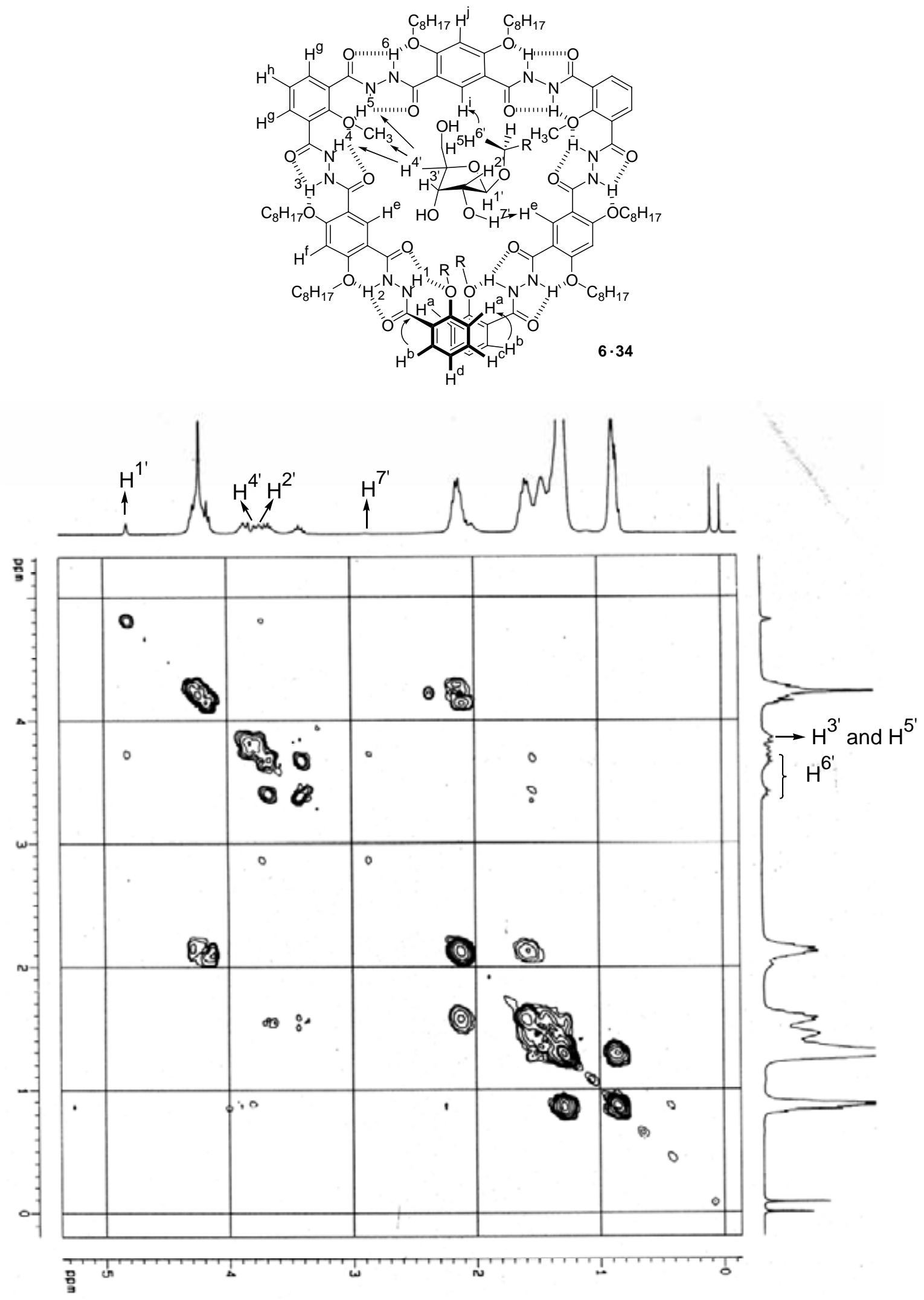

Figure 13. Partial ${ }^{1} \mathrm{H}$ NMR COSY spectrum (500 MHz) of the mixture of $6(8.0 \mathrm{mM})$ and 34 $(8.0 \mathrm{mM})$ in $\mathrm{CDCl}_{3}$ at $23^{\circ} \mathrm{C}$. 

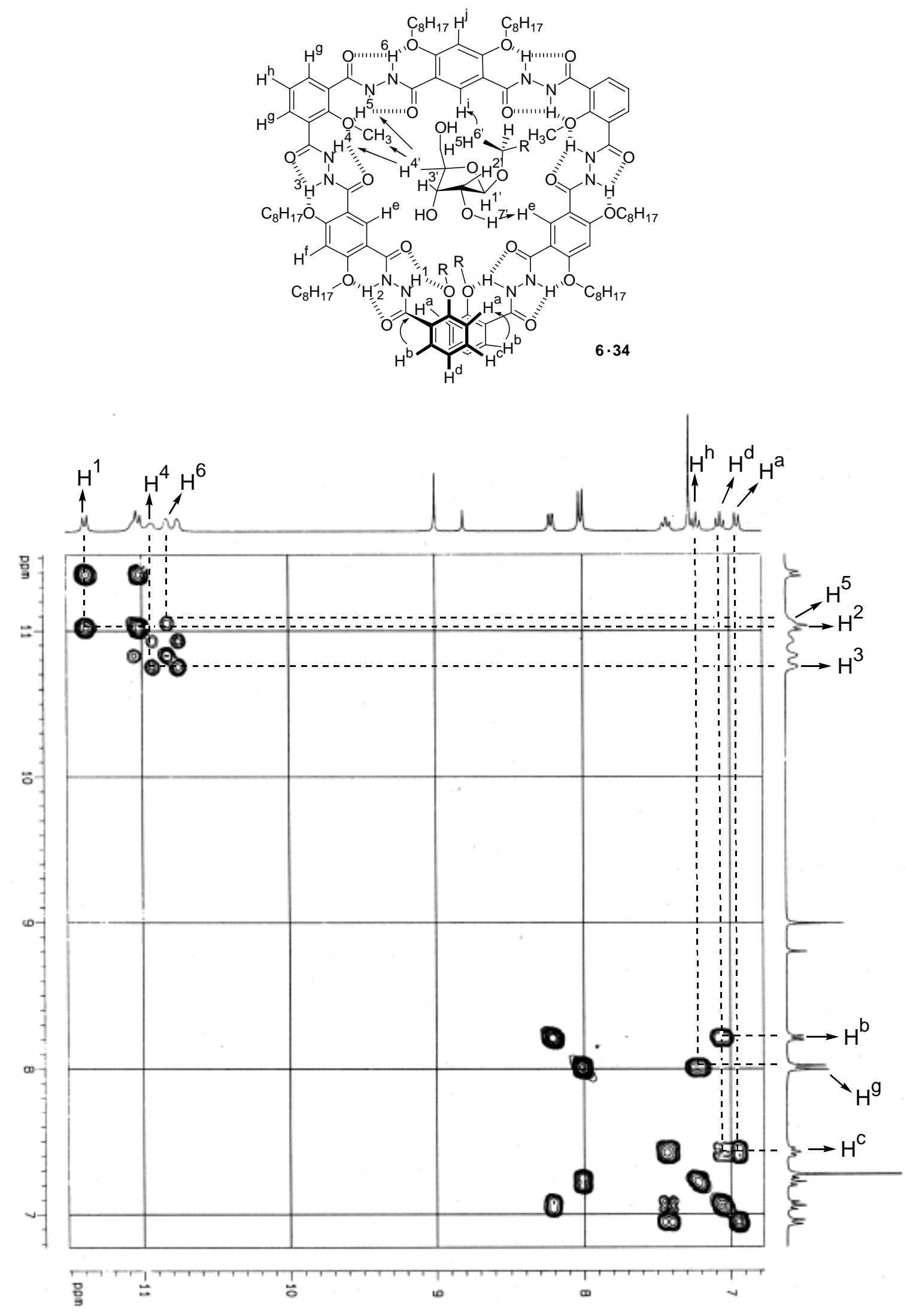

Figure 14. Partial ${ }^{1} \mathrm{H}$ NMR COSY spectrum (500 MHz) of the mixture of $6(8.0 \mathrm{mM})$ and 34 (8.0 mM) in $\mathrm{CDCl}_{3}$ at $23^{\circ} \mathrm{C}$. 

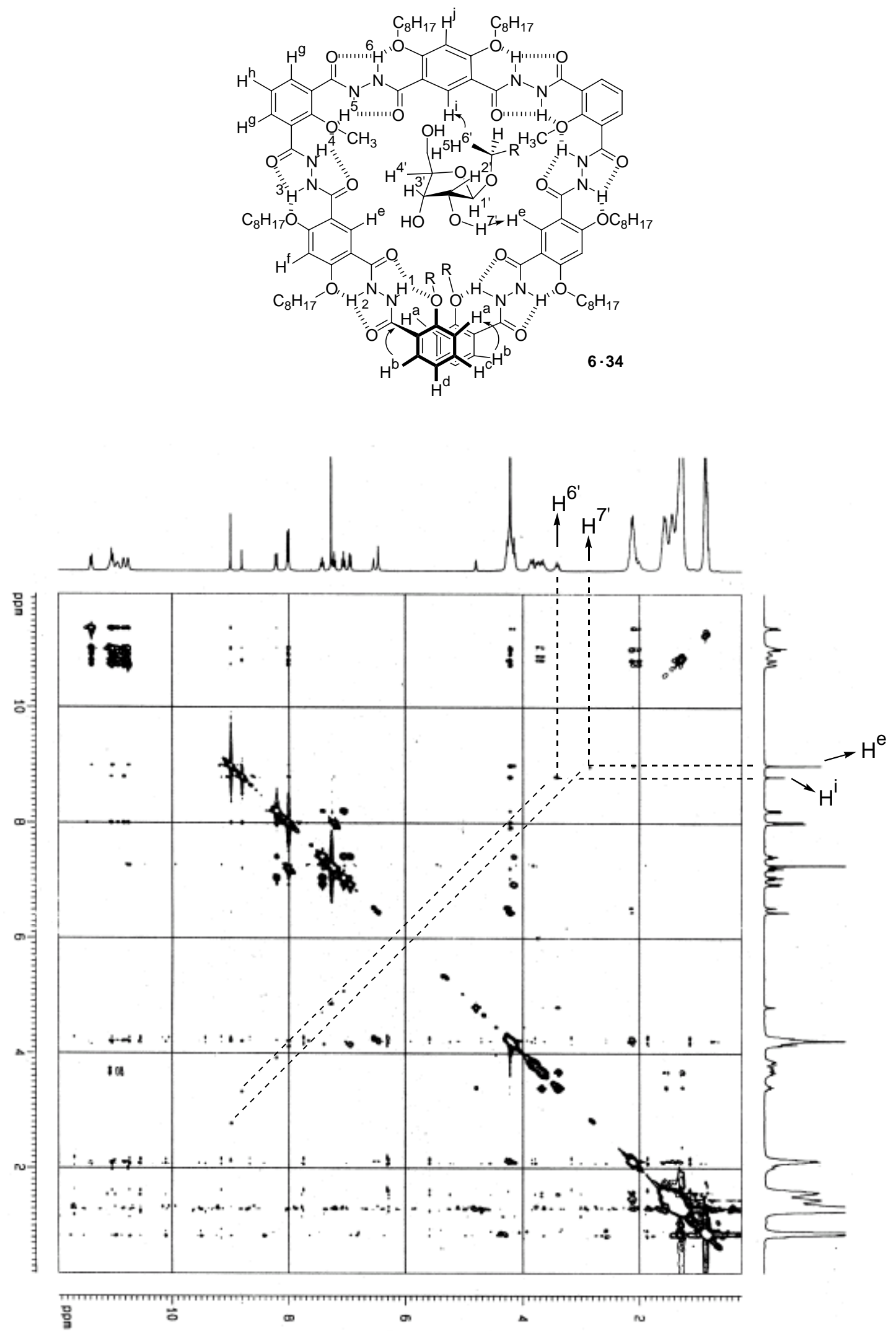

Figure 15. Partial ${ }^{1} \mathrm{H}$ NMR NOESY spectrum (500 MHz) of the mixture of $6(8.0 \mathrm{mM})$ and $34(8.0 \mathrm{mM})$ in $\mathrm{CDCl}_{3}$ at $23{ }^{\circ} \mathrm{C}$ (mixing time $=1 \mathrm{~s}$ ). 

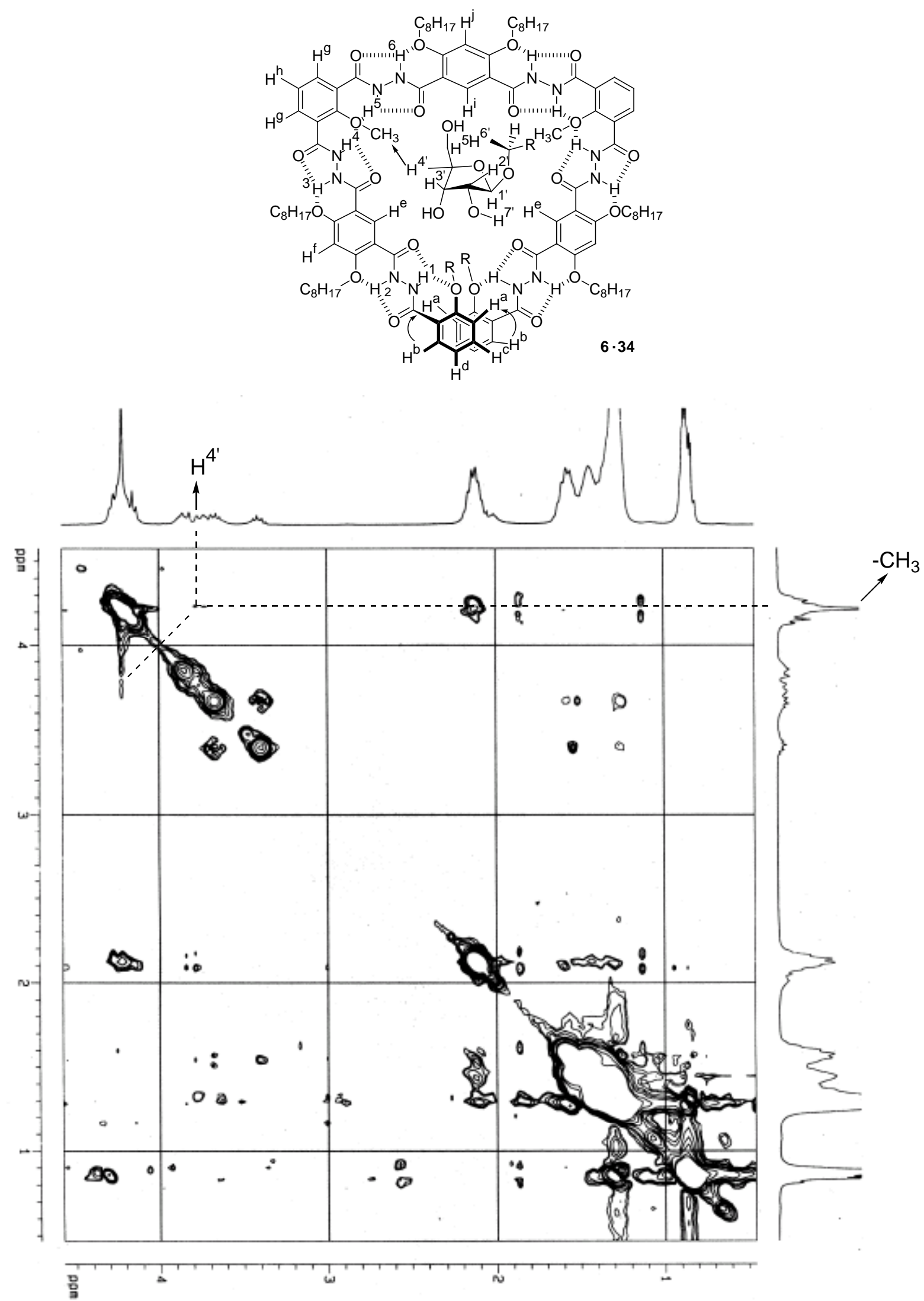

Figure 16. Partial ${ }^{1} \mathrm{H}$ NMR NOESY spectrum (500 MHz) of the mixture of $6(8.0 \mathrm{mM})$ and $34(8.0 \mathrm{mM})$ in $\mathrm{CDCl}_{3}$ at $23{ }^{\circ} \mathrm{C}$ (mixing time $=1 \mathrm{~s}$ ). 

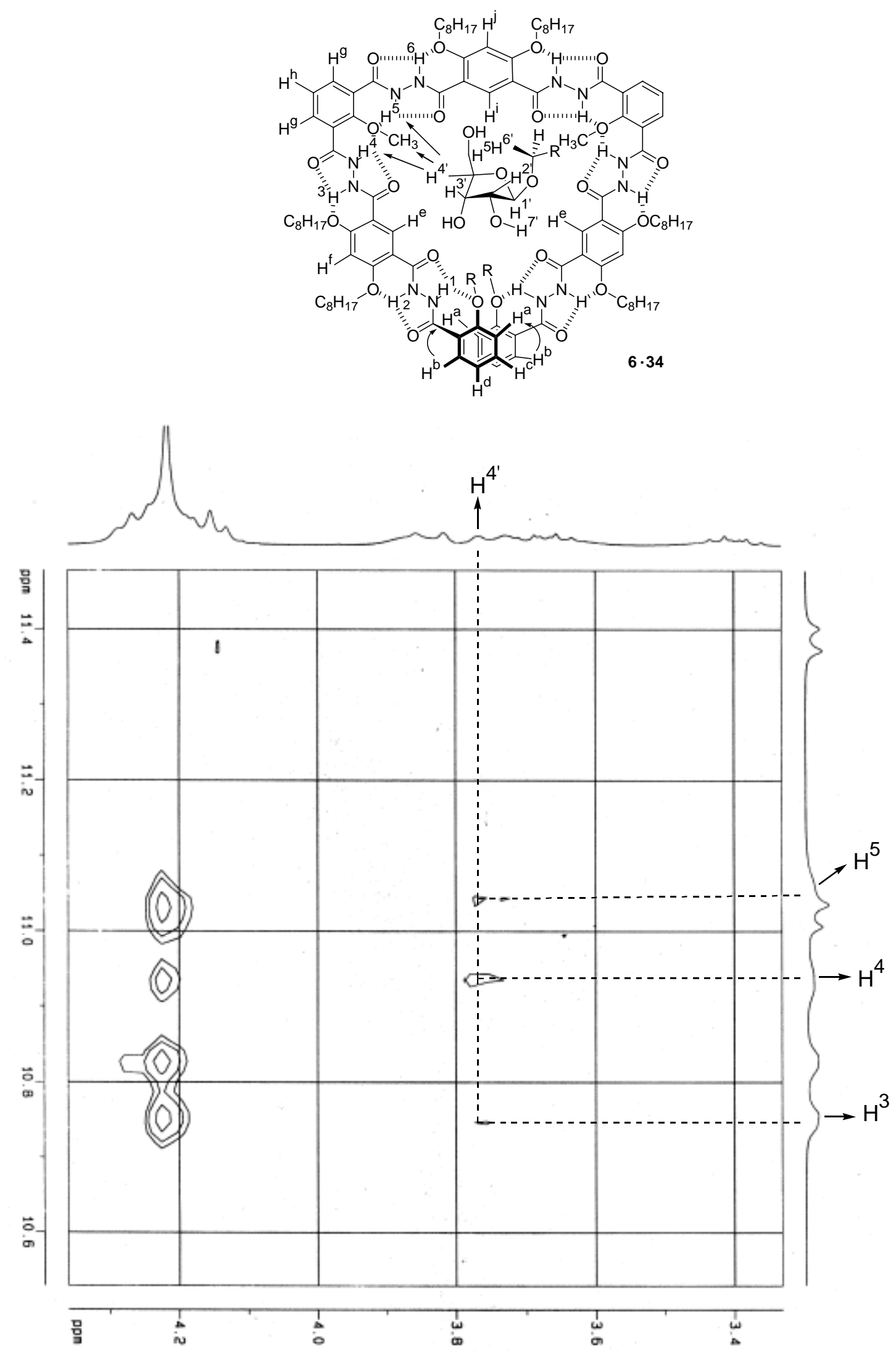

Figure 17. Partial ${ }^{1} \mathrm{H}$ NMR NOESY spectrum (500 MHz) of the mixture of $6(8.0 \mathrm{mM})$ and $34(8.0 \mathrm{mM})$ in $\mathrm{CDCl}_{3}$ at $23{ }^{\circ} \mathrm{C}$ (mixing time $=1 \mathrm{~s}$ ). 


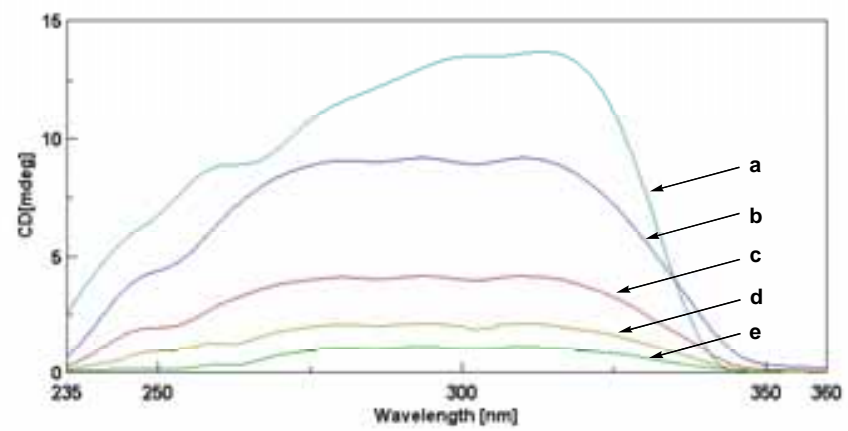

Figure 18. Concentration-dependent CD spectra of complexes between 6 and 34 (1:1) at 23 ${ }^{\circ} \mathrm{C}$ : a) $0.3 \mathrm{mM}$, b) $0.2 \mathrm{mM}$, (c) $0.1 \mathrm{mM}$, (d) $50 \mu \mathrm{M}$, and (e) $25 \mu \mathrm{M}$.

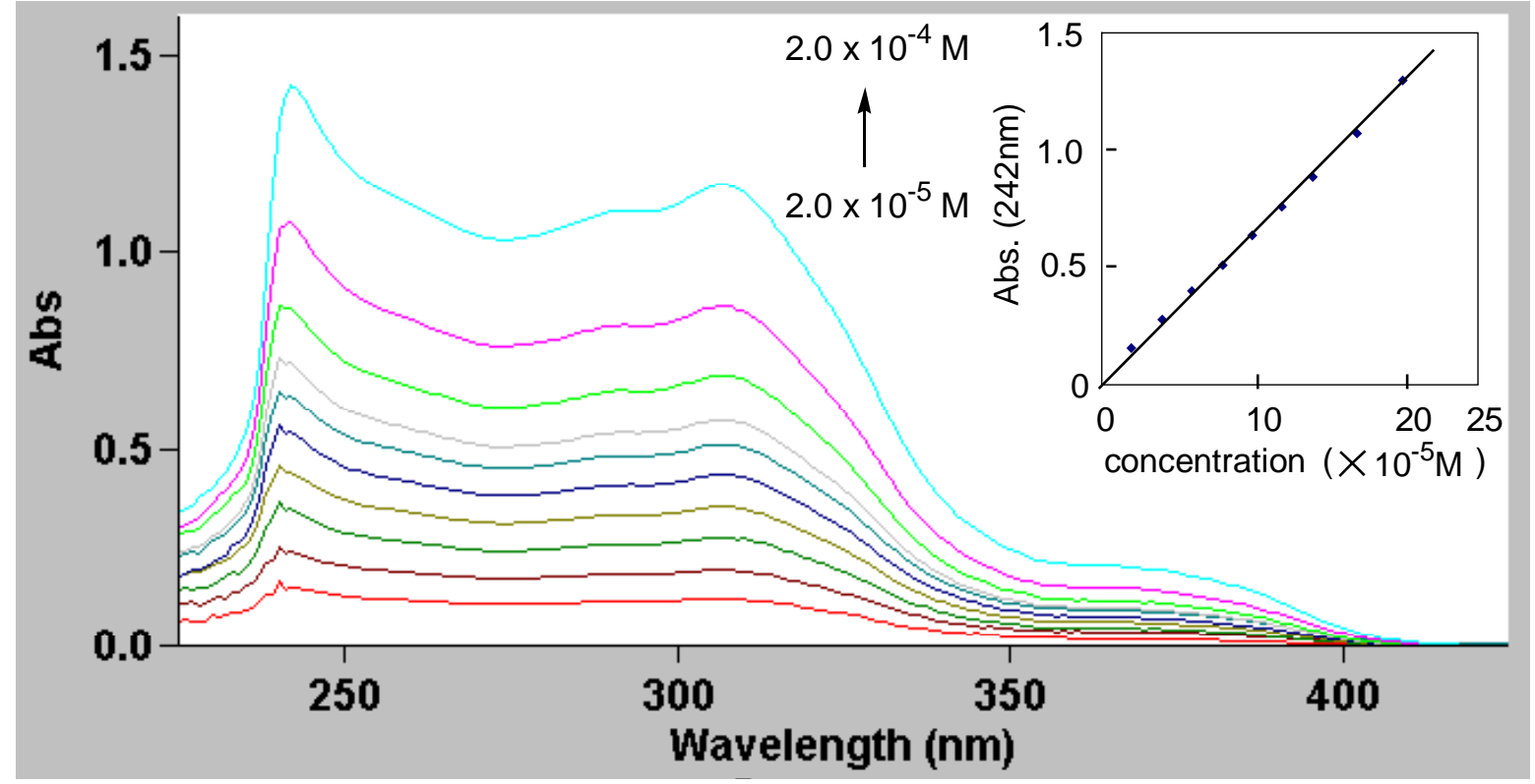

Figure 19. Concentration-dependent UV spectra of 7 in chloroform at $23{ }^{\circ} \mathrm{C}$. 


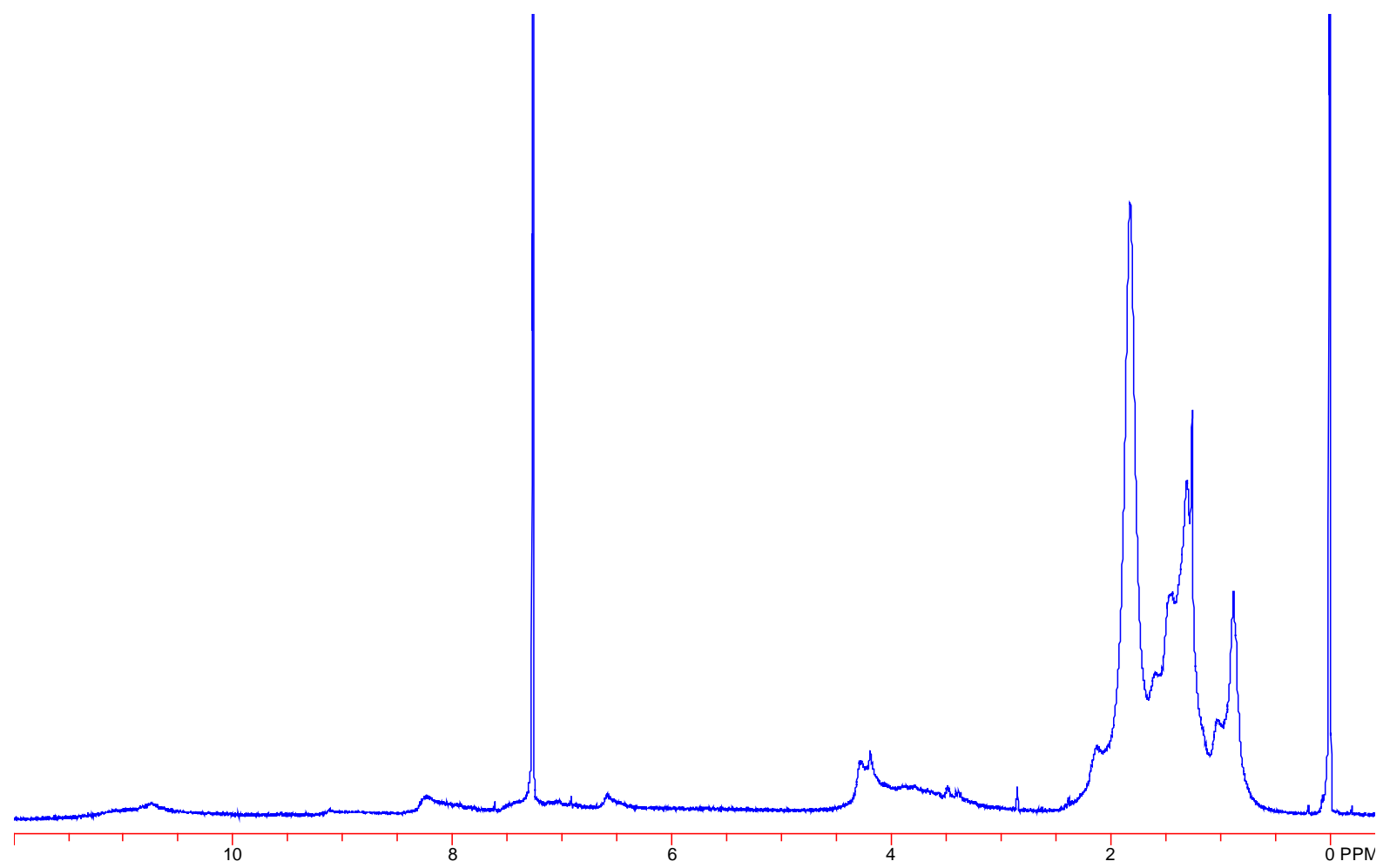

Figure 20. ${ }^{1} \mathrm{H}$ NMR spectrum $(400 \mathrm{MHz})$ of $7(0.1 \mathrm{mM})$ in $\mathrm{CDCl}_{3}$ at $23{ }^{\circ} \mathrm{C}$.

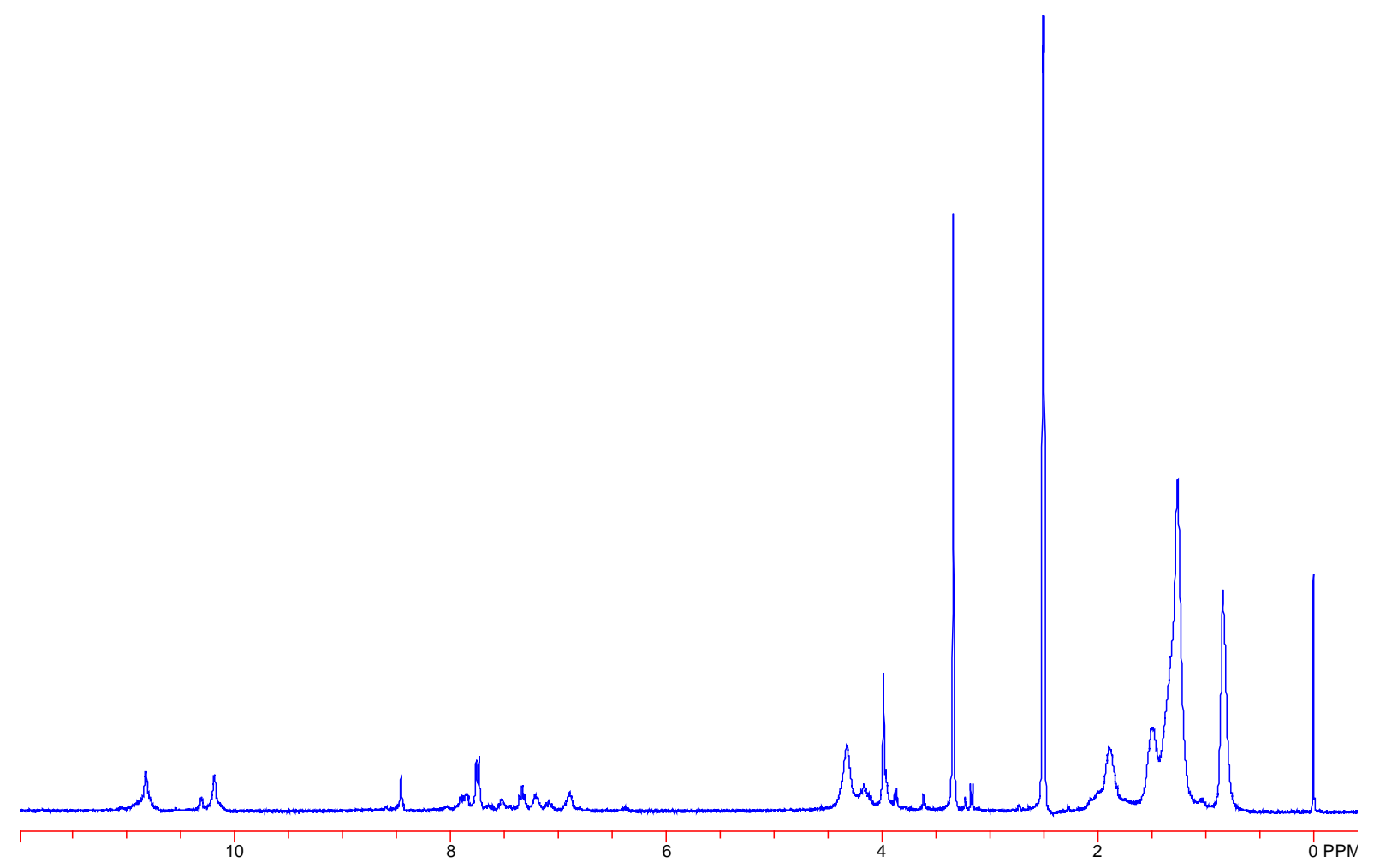

Figure 21. ${ }^{1} \mathrm{H}$ NMR spectrum $(400 \mathrm{MHz})$ of $7(2 \mathrm{mM})$ in $\mathrm{DMSO}-\mathrm{d}_{6}$ at $23{ }^{\circ} \mathrm{C}$. 


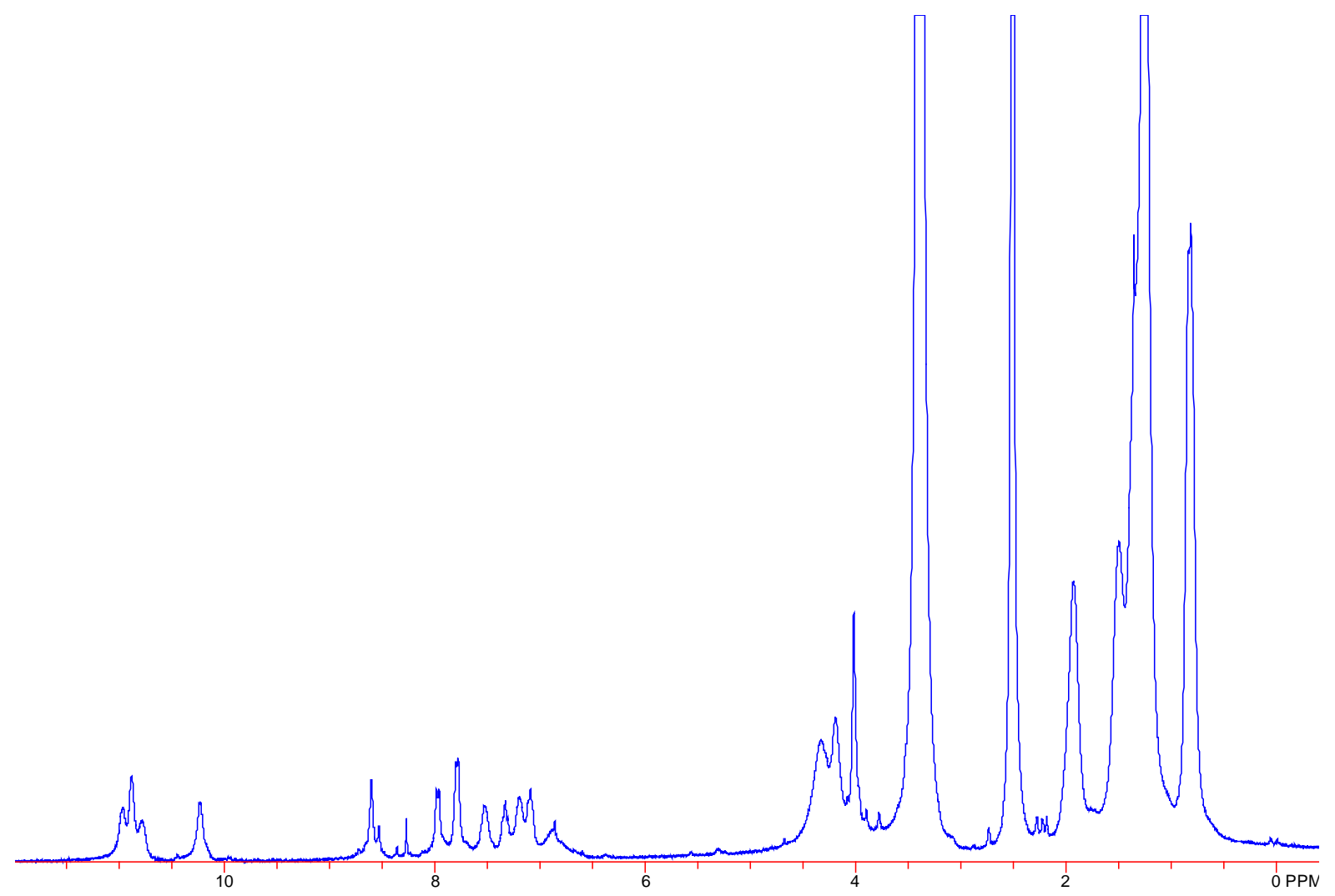

Figure 22. ${ }^{1} \mathrm{H}$ NMR spectrum $(400 \mathrm{MHz})$ of $6(2 \mathrm{mM})$ in $\mathrm{DMSO}^{-\mathrm{d}_{6}}$ and $\mathrm{CDCl}_{3}(9: 1 \mathrm{v} / \mathrm{v})$ at $23{ }^{\circ} \mathrm{C}$. 

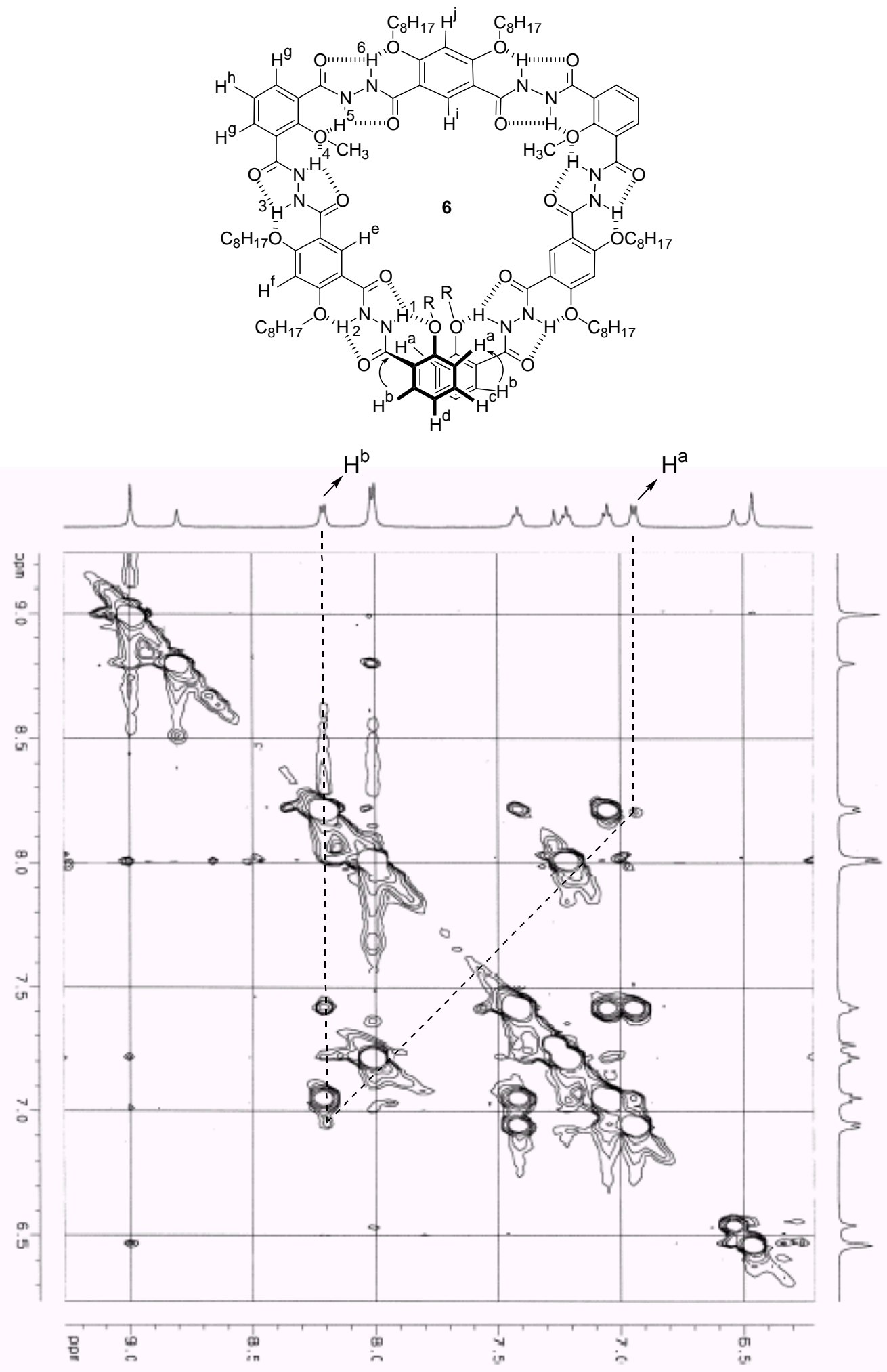

Figure 23. Partial ${ }^{1} \mathrm{H}$ NMR NOESY spectrum $(400 \mathrm{MHz})$ of $6(8.0 \mathrm{mM})$ in $\mathrm{CDCl}_{3}$ (mixing time $=0.5 \mathrm{~s}$ ). 

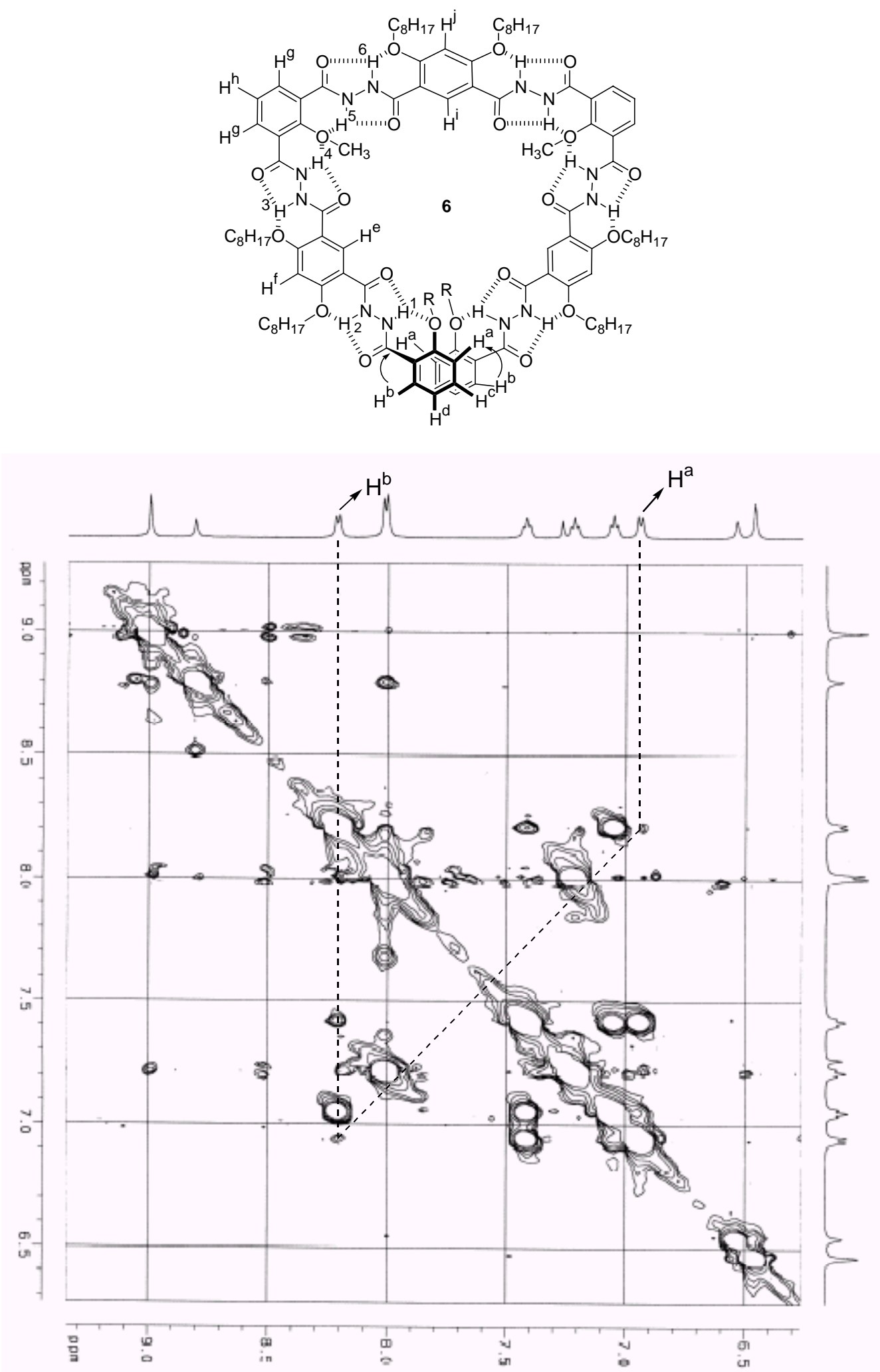

Figure 24. Partial ${ }^{1} \mathrm{H}$ NMR NOESY spectrum $(400 \mathrm{MHz})$ of $6(8.0 \mathrm{mM})$ in $\mathrm{CDCl}_{3}$ (mixing time $=0.25 \mathrm{~s}$ ). 